\title{
WATERWAYS IN THE INLAND NAVIGATION LAW
}

\author{
Moshak G. G.
}

\section{INTRODUCTION}

The development of inland water transport until 2030 provides for its construction on the basis of a sound political strategy supported by sufficient and effective implementation tools - coordination, investments, legislation. The aim of the study is to analyze the concept of waterway in inland navigation law based on the materials of Ukraine and individual Danube countries, study the practice of its application in the context of the economic situation. This will make it possible to formulate conclusions and proposals for its improvement.

The share of transported goods by inland waterways in the structure of transportation by all modes of transport in Ukraine is about $1 \%$, while in the European Union it is $7 \%$, in Germany - $12 \%$, in Romania - $22 \%$.

The existence in Germany of numerous sources - fundamental laws and large volume of comments, monographs and scientific articles written on the materials of court cases, opens the prospect of borrowing the German positive experience in the definition of the concepts of inland navigation law.

A comparative analysis of the concept of "inland waterway" revealed the existence of factors that do not contribute to its scientific and legislative definition. They erase the boundary between the inland navigation law and the law of the sea; distort the real proportion of transport carried out by individual modes in Ukraine, Moldova and Romania.

\section{LEGAL APPROACHES TO THE PROBLEM OF INLAND WATERWAYS OF THE DANUBE COUNTRIES}

It follows from the latest foreign studies that the concept of inland waterway is an important component of water transport development and inland navigation law. The formulation of this concept has a theoretical and practical meaning, as it influences the results of law-making, science and practice, in particular, the allocation of transportation to inland waterway or sea transport, and the processing of goods - in ports on inland waterways or sea routes. The Resolution of the Cabinet of Ministers of Ukraine No. 640 dated 12.06.1996 referred the Ukrainian part of the river Danube (from Reni to Vilkovo, as well as the Danube-Black Sea channel) to the sea route. In the cities of Reni, Izmail, Kilia, Vilkovo and Ust-Dunaysk there are not any river ports, but sea ports. The sea port in Kherson is located on the Dnieper River, $95 \mathrm{~km}$ from the sea. The granting of the status of sea to the port, located on the 
inland waterway, is also observed in some other countries. In particular, the seaport of Hamburg is located on the River Elbe about $100 \mathrm{~km}$ from the North Sea. Interpretation of the concept of an inland waterway with its deviation from the legal and substantive basis forms a legal theoretical and practical problem, which has not been studied in Ukraine, Romania and Germany.

The concept of "inland waterway" was used in the works of prerevolutionary scientist of Kazanskij P. E. ${ }^{1}$, in the works of contemporaries Kulko A. V. ${ }^{2}$, Efimenko A. P. ${ }^{3}$, Samoilenko G. V., Samoilenko E. A. ${ }^{5}$ the author of these lines ${ }^{6}$, and other scientists.

However, a study of the concept of "inland waterway", its connection with the theory of law, legislation, and law enforcement is absent in modern domestic legal literature. The research results of this problem have not been published in the English, German, Romanian literature, no attention was paid to the link between the content of the concept and the ratio of inland waterway and sea transport.

${ }^{1}$ Kazanskiy P. "Dohovirnirichky: Narysy istoriyi ta teoriyi mizhnarodnoho richkovoho prava" ["Contractual Rivers: Essays on the History and Theory of International River La"] T. 1-2 / Kazans'kyy P., priv. dots. Imp. Kazan. un-tu. Kazan': Typo-lyt. Imp. un-tu: Typ. Hub. pravl., 1895. 872 s. repryntne kopiya.

${ }^{2}$ Kul'ko A. V. "Instytutsiyni ta dohovirni mekhanizmy rehlamentatsiyi mizhnarodnoho spivrobitnytstva z vykorystannya resursiv riky Dunay" ["Institutional and contractual mechanisms for regulating international cooperation on the use of Danube river resources"]:avtoref. dys... kand. yuryd. nauk: 12.00.11 / A.V. Kul'ko ; Kyyiv. nats. un-t im. T. Shevchenka. K., 2009. 19 s. ukp. Kul'ko A.V. Mizhnarodno-pravove rehulyuvannya vykorystannya ta okhorony transkordonnykh prisnykh vod 12.00.11 - mizhnarodne pravo avtoreferat dysertatsiyi na zdobuttya naukovoho stupenya doktora yurydychnykh nauk Kyiv. 2018. avtoreferat dysertatsiyi na zdobuttya naukovoho stupenya doktora yurydychnykh nauk Kyiv, 2018. URL: http://idpnan.org.ua/files/kulko-a.v.-mijnarodnopravove-regulyuvannya-vikoristannya-ta-ohoroni-transkordonnih-prisnih-vod-_a_.pdf (zvernennya: 18.06.2019 r).

${ }^{3}$ Yefymenko A. P. "Mizhnarodno-pravovyy rezhym Dunayu: aspekty sudnoplavstva ta okhorony navkolyshn'oho seredovyshcha". ["International legal regime of the Danube: aspects of navigation and environmental protection"] Spetsial'nist' 12.00.11 - mizhnarodne pravo. Avtoreferat. - dysertatsiyi na zdobuttya naukovoho stupenya kandydata yurydychnykh nauk. Kyiv, 1998. 20 s.

4 Samoylenko H. V. "Dohovir vantazhiv u vnutrishn'omu vodnomu spoluchenni”. [“Cargo contract in inland waterway connection".] Spetsial'nist': 12.00 .03 - tsyvil'ne pravo ta tsyvil'nyy protses; simeyne pravo; mizhnarodne pryvatne pravo. - avtoreferat dysertatsiyi na zdobuttya naukovoho stupenya kandydata yurydychnykh nauk. Kharkiv 2003.

${ }^{5}$ Samoylenko Ye. A. mizhnarodno-pravove rehulyuvannya navihatsiynoho vykorystannya mizhnarodnykh rik.-avtoreferat dysertatsiyi na zdobuttya naukovoho stupenya kandydata yurydychnykh nauk. Kyiv, 2016. $46 \mathrm{~s}$.

${ }^{6}$ Moshak H. H. "Pravovyy kontrol' vykorystannya richky Dunay". ["Legal control of the use of the Danube River"]. Odesa, "Yurydychna literature", 2005, 48 s. 
Comparative study of the concept of waterway in the law of inland navigation on the materials of Ukraine and individual Danube countries aims to deepen understanding of the problem, to determine the validity and substantive correctness of the transfer to activities inland waterways maritime terminology, as well as suggesting approaches to solving the problem. We have studied the legislation and practice of using the concept of "inland waterway" on materials that are little known or absent in Ukraine. The conducted analysis allowed us to see the previously unknown legal nature of this concept and to formulate proposals for its improvement.

According to the existing practice in Ukraine, a port on a river is called a sea port if it is capable of receiving sea vessels. The consequence is actually incorrect and legally groundless extension of the maritime law to transport operations on inland waterways and ports. Thus, the share of cargo processing on inland waterways and ports is reduced. The share of transportation by this or that mode of transport affects the distribution of financial resources and the amount of support provided by the state to the most powerful carriers. Inland navigation and the right of inland navigation benefit from it. At the same time, the declaration of the European Federation of Inland Ports for the development of the transport sector and ports on inland waterways until 2030 considers legislation as an important tool for smart transport and logistics without transshipment.

The development of certain institutions of inland navigation law is conditioned by the level of development of this sector of transport and conceptual apparatus.

It creates one of the foundations for the existence of law. The development of the concept of "inland waterway", legal regulation of the use of infrastructure - are among the key conditions for the existence of inland water transport, forming the environment for its functioning.

The study of the legal problem of inland waterway only on the basis of the materials of Ukraine would be incomplete if the experience of the countries, which occupy the leading positions in transportation, were left without attention. Common problems of Danube navigation law require cooperation of Ukraine with Danube countries such as Romania, Moldova, Austria and Germany in developing the concept and status of inland waterways. The share of inland waterway transportation in the structure of transportation by all modes of transport in Ukraine is about $1 \%$, while in the European Union $7 \%$, in Germany $-12 \%$, in Romania $-22 \%$. Significantly higher than in Ukraine, the Danube countries are not the limit of the possible. In a nonDanube country, the Netherlands reached $44.7 \%$ in 2017.

The analysis shows that in 2018 Romania ranked 3rd in the EU in terms of inland water transport (second only to Germany and the Netherlands). The 
Romanian part accounts for $9 \%$ of the EU transport volume ${ }^{7}$. Romania is one of the coordinators of the EU Danube Strategy for the Danube Region.

Inland waterway transport in Romania decreased from 8700,000 tons in 1998 to 2900,000 tons in 2009. The reduction of transport in Ukraine, Moldova and other Danube countries since the 90s finally led to a number of unresolved legal problems. Calculations show that, due to poor infrastructure, it is more profitable for Romanian investors to import goods to the city of Timisoara through the Dutch port of Rotterdam, although the distance to it is $1,000 \mathrm{~km}$ more than the Romanian port of Constanta ${ }^{8}$.

The reduction in traffic in Germany was relatively small and did not result in a reduction in inland waterway length. In Germany it is $7,300 \mathrm{~km}$, which continue to be used effectively for shipping purposes. Among the Danube countries, the biggest reduction in the length of river public shipping lanes occurred in Ukraine: from 4,910.0 km in 1980 to $1,569.4 \mathrm{~km}$ in 2016. The volume of transportation by river transport in Ukraine of 67 million tons per year (recorded in 1990) decreased to 8 million tons ${ }^{9}$. However, the huge potential of Ukraine's inland waterways remains ${ }^{10}$ and requires unambiguous terms in law and inland navigation law.

The appeal to the right of inland navigation of the Federal Republic of Germany is argued by its leadership position. Laws with a century-long history and detailed comments, substantial monographs and articles written on case files, reflect a boom in development of German inland navigation law and the clarity of its conceptual apparatus. More than ten special laws regulate the relations of inland navigation ${ }^{11}$. The most important of these is the Act on

7 Jahresbericht 2018 Europäische Binnenschifffahrtmarktbeobachtung. URL: https://www.ccr-zkr.org/files/documents/om/om18_II_de.pdf (accessed 18.06.2019).

${ }^{8}$ Paradoxul cu care se confruntă România. Investitorii preferă să importe prin portul olandez Rotterdam.-https://www.digi24.ro/stiri/economie/transporturi/de-ce-investitorii-dinvestul-tarii-prefera-sa-importe-prin-portul-olandez-rotterdam-875078 (accessed 18.06.2019).

9 Informatsiya pro vodnyy transport Ukrayiny" ["Information about water transport of Ukraine"] URL: https://mtu.gov.ua/content/informaciya-pro-vodniy-transport-ukraini.html (zvernennya:18.06.2019 r).

${ }^{10}$ Informatsiya pro vodnyy transport Ukrayiny. Ukrayina maye 3 sudnoplavni richky, dvi z yakykh vkhodyat' do TOP-5 naybil'shykh richok Yevropy, 16 richkovykh portiv ta terminaliv; $60 \mathrm{mln}$. tonn propusknoyi zdatnosti na rik. [Information about water transport of Ukraine. Ukraine has 3 navigable rivers, two of which are among the top 5 largest rivers in Europe, 16 river ports and terminals; 60 million tonnes of throughput per year.]. URL: https://mtu.gov.ua/content/informaciya-pro-vodniy-transport-ukraini.html (zvernennya:04.10.2019)

${ }^{11}$ Ein Service des Bundesministeriums der Justiz und für Verbraucherschutz sowie des Bundesamts für Justiz. URL: (zvernennya:07.10.2019) 
Private Legal Relations in Inland Navigation (Binnenschiffahrtsgesetz) ${ }^{12}$, which has been in operation for over 100 years, since January 1, 1896. It is analyzed in Germany in most authoritative publications. In my translation from German, the Law is available on the Internet ${ }^{13}$. Austria has a law with the same name. Comments of Otto Vortisch and Otto Zschucke to the "Law on Inland Navigation and Rafting: an Explanatory Text" - were published in 1938, republished in 1953 and $2016^{14}$; the fourth edition of the "Commentary on Inland Navigation Law" by A. Vortisch and W. Bemm ${ }^{15}$ was published in 1999; the fifth edition of the "Commentary on Inland Navigation Law" was published in 2007; the fifth edition of the "Commentary on Inland Navigation Law" by T. Waldstein and J. Holland ${ }^{16}$ also analyses the previously mentioned German Law.

Comparative analysis of the notion of inland waterway in the law of Ukraine, Moldova, Romania and Germany showed that there are differences, which may adversely affect the quality of legal regulation of shipping relations and its indicators. The quality of the concept wording determines the limits of legal regulation and, as a result, may affect the calculation of the proportion of transportation carried out by water transport modes. Vague definition of the concept of inland waterway distorts the boundaries of navigation and the law governing it.

The reference to the Encyclopedia Britannica shows, that in the concept of inland waterway it first sees canals, and only then - all other natural or artificial waterways that are used for navigation, crop irrigation, water supply or drainage. At the same time, it is noted that in transport, inland waterways play a vital role

${ }^{12}$ BinSchG - Binnenschiffahrtsgesetz. Ein Service des Bundesministeriums der Justiz und für Verbraucherschutz sowie des Bundesamts für Justiz. URL: http://www.gesetze-iminternet.de/binschprg/ (zvernennya:07.10.2019).

${ }^{13}$ Pereklad Zakonu dyv. za adresoiu: http://uidree.org.ua/ (zvernennia 18.06.2019 r.)

14 Binnenschiffahrts- und Flößereirecht: Erläuterungswerk / Otto Vortisch; Otto Zschucke. Verlag Berlin: de Gruyter, Erscheinungsdatum: 1938, Umfang/Format XIX, 922 s. URL: https://portal.dnb.de/opac.htm?method=showFullRecord\&currentResultId= $\% 22$ Binnenschiffahrts- $\% 22+$ and $+\% 22$ und $\% 22+$ and $+\% 22 \mathrm{Fl} \% \mathrm{C} 3 \% \mathrm{~B} 6 \% \mathrm{C} 3 \% 9$ Fereirecht $\% 3$ A\%22+and+\%22Erl\%C3\%A4uterungswerk\%22\%26any\&currentPosition=1 (звернення: 07.10.2019).

${ }^{15}$ Binnenschiffahrtsrecht : Kommentar / Vortisch, Otto, Bemm, Wilfrid .- Ausgabe 4., völlig neu bearb. Aufl. / - Verlag Berlin ; New York : de Gruyter, Erscheinungsdatum: 1991. 819 s. URL: https://portal.dnb.de/opac.htm?query=Otto+Vortisch \%2C+Wilfrid+ Bemm\&method=simpleSearch (звернення: 07.10.2019).

16 Binnenschiffahrtsrecht: Kommentar / von Thor v. Waldstein; Hubert Holland. Ausgabe 5., völlig neu bearb. Aufl., Verlag Berlin : de Gruyter Recht, Erscheinungsdatum: 2007. $1104 \quad$ s.; URL: https://portal.dnb.de/opac.htm?method=showFullRecord\& currentResultId=Thor+and+v.+and+Waldstein \%26any\&currentPosition=7 (07.10.2019) 
and in many areas have a perspective of development ${ }^{17}$. The authoritative German encyclopedic dictionary Duden defines the land route as an inland waterway, and surrounded by it from all sides. It is, for example, a river or canal. The interpretation of the term "inland waterway" in the German Federal Waterways $\mathrm{Act}^{18}$ is slightly different, where the emphasis is not on distinguishing between inland waterways and sea routes, and on federal or other waterways.

\section{LEGISLATIVE ASPECTS OF THE INLAND WATERWAYS OF THE DANUBE COUNTRIES}

Section 1 of the Federal Waterways Act defines them as routes intended for general use. The list of inland waterways in Germany in Annex 1 of the Act includes, for example, the Elbe and Danube rivers. Inland waterways are similarly listed in $\S 15$ of the Federal Act of 1997 on Inland Navigation$\mathrm{SchFG}^{19}$. Inland waterways are the Danube rivers (including the Vienna Danube Canal), rivers Ans, Traun and March with all their tributaries, side channels, harbours and branches (except for parts of watercourses listed in Annex No. 2). A total of 130 waterways are mentioned in the normative act. In Austria, the requirements for navigable waterways ( $\$ 2$ of the Act), including the parameters of the fairway, are determined by regulations based on intergovernmental agreements. Under the concept of inland waterway the German authors of the fifth edition of the Commentary "Law of Inland Navigation" T. Waldstein and H. Holland understand inland waterways as all inland waterways. In other words, natural streams, rivers, waterways and sea areas, as well as artificial waterways and canals. The authors refer fairly to the law of the sea and claim, that the same responsibility for water transport has been introduced in Germany since 1998. As a result, the difference between the law of the sea and the law of inland navigation on the question of liability has disappeared. The decisive factor was the intended use of the vehicle, whether it is for use on inland waterways or seaways ${ }^{20}$. As far as Ukrainian reality is concerned, this is the subject of a separate study. Irrespective of the

17 Canals and inland waterways. Encyclopaedia Britannica URL: https://www.britannica.com/technology/canal-waterway (3 18.06.2019 p).

${ }^{18}$ Bundeswasserstraßengesetz (WaStrG) .- Ein Service des Bundesministeriums der Justiz und für Verbraucherschutz sowie des Bundesamts für Justiz. URL: www.gesetze-im-internet.de URL: https://www.gesetze-im-internet.de/wastrg/WaStrG.pdf / (accessed: 07.10.2019)

${ }^{19}$ Bundesgesetz über die Binnenschifffahrt (Schifffahrtsgesetz - SchFG) StF: BGBl. I Nr. 62/1997 (NR: GP XX RV 564 AB 618 S. 67. BR: 5400 AB 5420 S.624.). URL: https://www.ris.bka.gv.at/GeltendeFassung.wxe?Abfrage=Bundesnormen\&Gesetzesnumme $\mathrm{r}=10012703$ (accessed: 18.06.2019).

20 Thor v. Waldstein, Hubert Holland. Binnenschiffahrtsrecht: Kommentar. Berlin: de Gruyter Recht. 2007. S. 9-10. URL: https://books.google.com.ua/books?id=i7ViXw MMwokC\&printsec $=$ frontcover\&hl=ru\&source=gbs_ge_summary_r\&cad $=0 \# \mathrm{v}=$ onepage\&q\&f $=$ false $($ accessed 18.06.2019). 
fact, to what extent the legal liability for inland waterway and sea transport in Ukraine currently coincides, in the future, responsibility will be brought to EU standards as the state integrates into its legal space.

In electronic version "The Great Ukrainian Encyclopedia" there are no concepts of "waterway" and "inland waterway". Resolution No. $640^{21}$ of the Cabinet of Ministers of Ukraine lists sea and river navigable inland waterways. However, there is no justification for the distinction in this document. The lack of a definition of an inland waterway in domestic legislation stimulates its search in Danube law. Romania has a large network of inland waterways ${ }^{22}$, the list of which is nominal (i.e. not exhaustive ${ }^{23}$. This presupposes the possibility of its change in case of certain events. By legislating the list, the Romanian government has slightly narrowed it down compared to Ukraine because it did not include sea inland waterways. The definition of the concept of inland waterway in Romania was carried out by means of the concepts of national navigable waters and inland navigation waters. Inland waterways of Romania are not located in its inland maritime waters. From the Ordinance of Romania No. 42 of August 28, 1997 (with subsequent amendments) follows, that national navigable waters in Romania consist of a territorial sea, inland waterways, canals and port areas, as well as from shipyard pools. The navigable waters include the navigable parts of the Danube River, other rivers, canals and lakes located on the territory of Romania, as well as inland sea waters. Thus, it follows from the Ordinance, that inland waterways are navigable parts of the Danube River, watercourses, canals and lakes located within Romanian territory, as well as border waters from the Romanian coast to the border ${ }^{24}$.

Due to more efficient use of inland waterways by Romania than by Ukraine, its inland navigation legislation has evolved faster and more successfully. Romania's legislation has been positively influenced by its 10 -year membership in the European Union. For several decades, Romania has had a comprehensive act that not only lists inland waterways, as well as the

${ }^{21}$ Postanova KM Ukrayiny [Resolution of the CM of Ukraine] "Pro zatverdzhennya pereliku vnutrishnikh vodnykh shlyakhiv, shcho nalezhat' do katehoriyi sudnoplavnykh" ["On approval of the list of inland waterways belonging to the category of navigation."] vid 12 chervnya 1996 r. N 640. URL: https://zakon.rada.gov.ua/laws/show/640-96-\%D0\%BF (zvernennya: 07.10.2019)

${ }^{22}$ Lege 203/2003. REȚEAUA DECĂINA VIGABILE INTERIOARE ȘIPORTURI. URL: https://lege5.ro/Gratuit/gq2tonjr/reteaua-de-cai-navigabile-interioare-si-porturi-lege2032003 ?dp=gi3dcojzgq2tk. (accessed: 07.10.2019)

${ }^{23}$ HOTĂRÂREnr. 665 din 24 iunie 2008 pentru stabilirea nominală şipe porţiunia căilorna vigabile interioare ale României. URL: http://legislatie.just.ro/Public/ DetaliiDocument/95271. (accessed: 07.10.2019)

${ }^{24}$ ORDONANŢA nr. 42 din 28 august 1997 privind transportul maritim şi pe căile navigabile interioare. URL: https://portal.rna.ro/SiteAssets/Pagini/Legisla\%C8\%9Bie/ ORDONANTA\%2042.pdf. (accessed: 07.10.2019) 
rules for their use. This is Ordinance No. 22/1999 of the Romanian Government of January 29, 1999, which regulates management of waterways, use of navigable public transport infrastructure, as well as conducting shipping transport activities in ports and inland waterways. The Ordinance was amended in accordance with the requirements of time by Act No. 235 of 29 November 2017. On the amendment and completion of Government Ordinance No. $22 / 1999^{25}$ Domestic bill, that could be the first law in the history of an independent state, that would regulate the relationship in inland waterway transport, at the time of preparation of this article was still under consideration by the Verchovna Rada of Ukraine. However, for a variety of reasons, Romania's experience is closer to Ukraine than that of Germany. Ukraine is on the way to implementing the transformations that have recently been implemented in Romania in conditions similar to Ukraine.

According to the Moldovan point of view, the inland waterway is a communication path, natural or artificially created, nautical or otherwise and used for shipping purposes ${ }^{26}$. Article 2 of the Law on Inland Water Transport of the Republic of Moldova (Moldovan law is interesting from the point of view of its speed of change under the growing influence of Romanian law) is provided for, that the concept of an inland waterway is formed by listing its possible species, without using a list of geographical names. Thus, the concept of inland waterway has acquired a rather high level of generalization, has become meaningful. However, it is not sufficiently based on the 1982 United Nations Convention on the Law of the Sea, which articulates the internationally recognized notion of inland waters ${ }^{27}$.

It is well known that the socio-economic and material-technical basis of the right of inland navigation in Moldova is much smaller than in Ukraine. In 2018 Moldova owned only seven self-propelled cargo ships of its $\mathrm{own}^{28}$ and two

${ }^{25}$ Lege nr. 235 din 29 noiembrie 2017pentru modificarea și completarea Ordonanței Guvernului nr. 22/1999 privind administrarea porturilor și a căilor navigabile, utilizarea infrastructurilor de transport naval aparținând domeniului public, precum și desfășurarea activităţilor de transport naval în porturi și pe căile navigabile interioare. URL: http://legislatie.just.ro/Public/DetaliiDocument/195515 (accessed: 07.10.2019)

${ }^{26}$ Stattya 2 Zakona RM [Article 2 oftheLawofRM]"On the Inland Water Transport of the Republic of Moldova. URL: http://lex.justice.md/viewdoc.php?action=view\&view=doc\&id= 349950\&lang=2 (zvernennya: 07.10.2019)

27 Konventsiia Orhanizatsii Obiednanykh Natsii z morskoho prava, kotru stanom na cherven $2016 \mathrm{r}$ pidpysaly i ratyfikuvaly 168 krain i Yevropeiskyi soiuz, Ukraina ratifikavala 03.06.1999. URL: https://zakon.rada.gov.ua/laws/show/995_057 (zvernennia 18.06.2019 r).

28 Banca de date statistice Moldova. URL: http://statbank.statistica.md/pxweb/ pxweb/ro/40\%20Statistica\%20economica/40\%20Statistica\%20economica_19 \%20TRA_ TRA020/TRA020400.px/table/tableViewLayout1/?rxid=9a62a0d7-86c4-45da-b7e4fecc26003802. (accessed: 30.09.2019) 
self-propelled passenger ships ${ }^{29}$. At the same time, due to preferential conditions for registration under the Moldovan flag, in 2017 there were 168 seagoing vessels with a total capacity of 703,000 tons with temporary or permanent registration in the Danube Sea Port of Giurgiulesti. Formally, by tonnage, the Moldovan fleet is $10 \%$ of the Russian merchant fleet ${ }^{30}$, but only on paper does Moldova look like a real maritime power. Its navigable inland waterways were only $410^{31}$ to $635 \mathrm{~km}^{32}$ long in 2018 (depending on the method of calculation).

In previous years, the length of the routes was much longer ${ }^{33}$, however, Moldova lost its ownership share in the merchant fleet of the USSR with a total tonnage of 258,000 tons ${ }^{34}$. This led to a reduction in transportation and a decline in inland navigation law. According to the Unified State Register of Court Decisions in Ukraine, the number of court disputes in civil cases, where the subject was a riverboat, from 2014 to 2018, there was a dramatic increase of 10.1 times (from 52 to 528 decisions). In the case of maritime vessels, the increase in court decisions was only 2.9 times (180 decisions in 2014 and 826 in 2018). The table in the annex shows that there has been an increase, that there was a faster increase in the number of civil cases in inland navigation than in maritime shipping. The feature found may be one of the consequences of the aggravation of the civil situation in inland navigation law. It requires increased attention from scientists and the resolution of civil cases by civil law instruments.

${ }^{29}$ Banca de date statistice Moldova. Nave fluviale in inventar, la sfirsitul anului, pe tipuri de nave, 2000-2018 pe Tipuri de nave si Ani 2018 Nave de pasageri cu autopropulsie. (accessed: 30.09.2019)

${ }^{30}$ Pravyla reyestratsiyi suden v Moldovi zminyuyut'sya.[Rules for registering ships in Moldova are changing]- PortN'yus. URL: http://portnews.ru/digest/20781/.- (zvernennya: 30.09.2019).

${ }^{31}$ Ministerul Transporturilor. RAPORT DE ACTIVITATE pentru anul 2018. IUNIE 2019. Cai fluviale navigabile de folosinta generala. Lungimea cailor de comunicatie, la sfirsitul anului, 2000-2018 pe Indicatori si Ani 2018. URL: http://www.mt.gov.ro/ web14/documente/interes-public/rapoarte/Raport \%20activitate \%20MT \%202018.pdf (accessed: 30.09.2019)

32 Postanovlenye Pravytelstva RM Nr. 453 ot 24.03.2008 “Ob utverzhdenyy Kontseptsyy razvytyia vodnoho transporta v Respublyke Moldova” .-MonitorulOficialNr. 66-68 statia № : 433

33 "Karta yevropeys'kykh vnutrishnikh vodnykh shlyakhiv".["Map of European Inland Waterways "]-In: http://mapinmap.ru/archives/9552.- (zvernennya: 07.10.2019)

34 Labunets A. V. "Ekonomika Moldovy: problemy vodnoho transportu". In:https://ava.md/2010/07/15/ekonomika-moldovy-problemy-vodnogo["Moldova's economy: problems of water transport']-transporta/ .- (zvernennya: 30.09.2019) 
Table

Number of court decisions and convictions over the last 5 years according to the Unified State Register of Court Decisions for the context words "sea vessel", "river vessel"

\begin{tabular}{|c|c|c|c|c|c|c|c|c|c|c|}
\hline \multirow[t]{2}{*}{ Year } & \multicolumn{2}{|c|}{2014} & \multicolumn{2}{|c|}{2015} & \multicolumn{2}{|c|}{2016} & \multicolumn{2}{|c|}{2017} & \multicolumn{2}{|c|}{2018} \\
\hline & 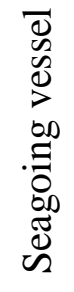 & 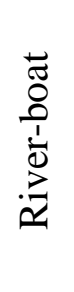 & 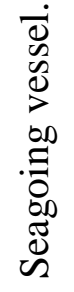 & 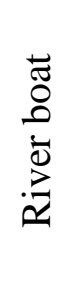 & 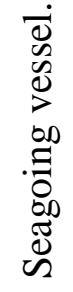 & 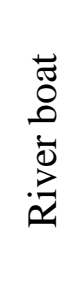 & 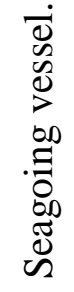 & 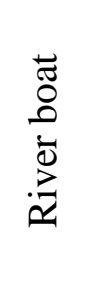 & 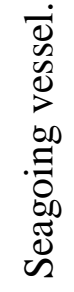 & 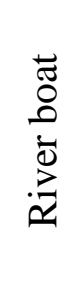 \\
\hline $\begin{array}{l}\text { Civil cases } \\
\text { (decision) }\end{array}$ & 180 & 52 & 178 & 63 & 293 & 196 & 292 & 185 & 826 & 528 \\
\hline $\begin{array}{l}\text { Criminal cases } \\
\text { (sentences) }\end{array}$ & 16 & 6 & 22 & 4 & 20 & 10 & 17 & 7 & 24 & 7 \\
\hline
\end{tabular}

The lack of unity of understanding of the concept of inland waterway may contribute to an increase in court disputes regarding the use of ships. In Ukraine in 2018 there were 901 vessels with total gross tonnage 503,188 register tons ${ }^{35}$, and 97 mixed vessels (self-propelled and non selfpropelled with gross tonnage less than 100) with total gross tonnage 5261 register tons.

In our opinion, granting a shipping lane status under the United Nations Convention on the Law of the Sea is legitimate and justified. The Ukrainian governmental list of inland waterways (including canals and inland lakes) is preferable to the foreign language considered. However, it does not fully meet the requirements of the European Agreement on Main Inland Waterways of International Importance (AGN). The Convention defines a coherent network of inland waterways of international importance as a coherent plan for its development. Since ports are part of this network, the name of the port must be subject to the name of the route of its location. The numbering of ports under the European Agreement provides for the inclusion in the name of the port of the route from which it is located. The existence of a sea route and seaports on the Ukrainian part of the Danube River is contrary to the provisions of the European Agreement, as well as to the rules that require the name of the thing to conform to its essence. Providing the port with the name of the sea only on the basis that it is able to receive sea vessels is not a sufficient argument. The Ukrainian names of

35 Rehistrova knyha suden. Kyiv, 2018. REGISTEROFSHIPS, 2019 KYIV. URL: http://shipregister.ua/pdf/reg-ships.pdf.- (accessed: 01.10.2019) 
the waterway on the Danube River and the names of ports on it shall be brought into conformity with the requirements of the European Agreement on Main Inland Waterways of International Importance (AGN). The hope for correction of this deficiency is connected with the provisions of the Agreement providing for construction of Ukrainian inland navigation ports of international importance in the cities of Reni, Izmail, Kilia, Ust-Dunaysk.

Prospects for applying a unified approach and criteria for developing a unified concept of inland waterway by Ukraine, Moldova and Romania are linked to their cooperation in a number of multilateral and bilateral international conventions, treaties and programmes. They cooperate on issues related to the law of inland navigation in the Danube Commission, within the TRACECA projects ${ }^{36}$, Euroregions "Dniester" and "Lower Danube", as well as in the implementation of the EU Strategy for the Danube Region $(\mathrm{EUSDR})^{37}$.

The Eastern Partnership programmes also provide opportunities for joint legal initiatives on cooperation with the EU on transport issues. Development of a common concept of inland waterway is possible as part of the preparation of recommendations to improve the work of inland waterway transport enterprises to attract freight for transportation (by eliminating bottlenecks in the application of inland navigation law) or joint training in the field of inland navigation law, in the preparation of educational, scientific and practical developments and recommendations. One alternative guideline in developing the concept of an inland waterway and its status could be Dutch legislation. There, the relations of inland navigation are mainly regulated by the codified rules of Articles 309 of the Dutch Civil Code (Title 8.8 Inland navigation vessel and things on board thereof (Articles 770-859); Title 8.9 Crew of an inland navigation vessel (Articles 860-879); Title 8.10 (Commercial) Operations (Articles 880-999); Title 8.11 Accidents (Articles 1000-1059); Title 8.12 Limitation of liability of the owner of an inland navigation vessel (Articles 1060-1079).

${ }^{36}$ Transportni protsesy ta mors'ki mahistrali. [Logistic processes and shipping lanes] II. Proekt mayster-planu "LOGMOS" - Dodatok 9.1. Ohlyad krayiny. Moldova. Zhovten' 2013 r. URL: http://www.traceca-org.org/fileadmin/fmdam/TAREP/65ta/Master_Plan/ MPA9.1MDRU.pdf.- (Zvernennya 07.10.2019).

37 Stratehiyeyu peredbacheno v t.ch. rozvytok vnutrishn'oho sudnoplavstva (koordinatory- Avstriya i Rumyniya.- Stratehiya Yevropeys'koho Soyuzu dlya Dunays'kyy rehionu [The strategy provides, incl. development of inland navigation (coordinators Austria and Romania. - Strategy of the European Union for the Danube Region] (The EU Strategy for the Danube Region (EUSDR). URL: http://www.me.gov.ua/Documents/ Print?lang=uk-UA\&id=529fde16-08e8-45f8-ba31-6c9d36c01254. (звернення: 07.10.2019). 


\section{CONCLUSIONS}

In Germany, Austria, Romania and other countries the concept of a waterway in inland navigation law is based on public and private law. The lack of basic legislation regulating inland navigation in Ukraine is one of the factors of growing tension.

When developing the concept of an inland waterway, it is necessary to take into account that it is not the type of the vessel that determines the essence and name of the route or port, but vice versa. It is the concept of inland waterway and its characteristics that parameters of ships and ports shall be subject to.

In Ukraine, for the period until the completion of studying the experience of doctrinal and legislative definition of the concept of inland waterway the relevant developments of Germany, Austria, Romania could be used as workers.

\section{SUMMARY}

The above results of foreign studies point to the need for further development of the inland waterway concept and its normative expression as an important component of water transport development. Resolution of the Cabinet of Ministers of Ukraine No 640 of 12.06 .1996 for the Ukrainian part of the Danube River (from Reni to Vilkovo) extended to it the status of a sea route, which contradicted the European Agreement on Main Inland Waterways of International Importance (AGN). This contradiction is a consequence of deficiencies in the scientific definition of an inland waterway.

Previously, scientists have not analyzed and only mentioned the existence of inland waterways - beyond comparison with the law of the Danube countries Romania, Moldova and Germany. This study provides a modern understanding of the regulation of inland waterway relations in the Danube countries. It is based on the materials of Romania, Moldova, Germany and continues the research, which was initiated in the works of the prerevolutionary scientist of Kazanskij P. E., in the works of contemporaries Kulko A. V., Efimenko A. P., Samoilenko G. V., Samoilenko E. A.

\section{REFERENCES}

\section{List of legal documents}

\section{Legislation}

1. Banca de date statistice Moldova. [Statistical database Moldova]. URL: http://statbank.statistica.md/pxweb/pxweb/ro/40 \%20Statistica \%20economica/ $40 \% 20$ Statistica \%20economica_19 \%20TRA_TRA020/TRA020400.px/tab le/tableViewLayout1/?rxid=9a62a0d7-86c4-45da-b7e4-fecc26003802.

(zvernennya: 30.09.2019) 
2. Banca de date statistice Moldova.[ Statistical database Moldova]-Nave fluviale in inventar, la sfirsitul anului, pe tipuri de nave, 2000-2018 pe Tipuri de nave si Ani 2018 Nave de pasageri cu autopropulsie [River vessels in inventory, at the end of the year, by types of ships, 2000-2018 by types of ships and Years 2018 Passenger ships with self-propulsion] (zvernennya: 30.09.2019)

3. BinSchG - Binnenschiffahrtsgesetz. Ein Service des Bundesministeriums der Justiz und für Verbraucherschutz sowie des Bundesamts für Justiz. [BinSchG - Inland Shipping Act. A service of the Federal Ministry of Justice and Consumer Protection and the Federal Office of Justice.] URL: http://www.gesetze-im-internet.de/binschprg/ (zvernennya: 07.10.2019).

4. Bundesgesetz über die Binnenschifffahrt (Schifffahrtsgesetz SchFG)[Federal Law on Inland Navigation (Shipping Act - SchFG)]StF: BGBl. I Nr. 62/1997 (NR: GP XX RV 564 AB 618 S. 67. BR: 5400 AB 5420 S. 624.). URL: https://www.ris.bka.gv.at/GeltendeFassung.wxe?Abfrage=Bundesnormen \& Gesetzesnummer=10012703 (zvernennya 18.06.2019 r).

5. Bundeswasserstraßengesetz (WaStrG) [FederalWaterwaysAct (WaStrG)]. Ein Service des Bundesministeriums der Justiz und für Verbraucherschutz sowie des Bundesamts für Justiz [Aservice of the Federal Ministry of Justice and Consumer Protection and the Federal Office of Justice]. URL: https://www.gesetze-im-internet.de/wastrg/WaStrG.pdf (zvernennya: 07.10.2019)

6. HOTĂRÂRE nr. 665 din 24 iunie 2008 pentru stabilirea nominală şi pe porţiuni a căilor navigabile interioare ale României.[DECISION no. 665 of June 24, 2008 for the nominal and partial establishment of inland waterways of Romania.] URL: http://legislatie.just.ro/Public/DetaliiDocument/95271. (zvernennya:07.10.2019)

7. Lege 203/2003. - REȚEAUA DE CĂI NAVIGABILE INTERIOARE ŞI PORTURI. [INTERNAL NAVIGATOR NETWORK AND PORT]. URL: https://lege5.ro/Gratuit/gq2tonjr/reteaua-de-cai-navigabile-interioare-siporturi-lege-203-2003?dp=gi3dcojzgq2tk. (zvernennya: 07.10.2019)

8. Lege nr. 235 din 29 noiembrie 2017 pentru modificarea și completarea Ordonanței Guvernului nr. 22/1999 privind administrarea porturilor și a căilor navigabile, utilizarea infrastructurilor de transport naval aparținând domeniului public, precum și desfășurarea activităţilor de transport naval în porturi și pe căile navigabile interioare.[Law no. 235 of November 29, 2017 for amending and supplementing Government Ordinance no. 22/1999 on the administration of ports and waterways, the use of naval transport infrastructures belonging to the public domain, as well as the performance of naval transport activities in ports and inland waterways] URL: http://legislatie.just.ro/Public/DetaliiDocument/195515 (zvernennya: 07.10.2019) 
9. Postanova KM Ukrayiny [Resolution of the CM of Ukraine] "Pro zatverdzhennya pereliku vnutrishnikh vodnykh shlyakhiv, shcho nalezhat' do katehoriyi sudnoplavnykh" ["On approval of the list of inland waterways belonging to the category of navigation"] vid 12 chervnya 1996 r. N 640. URL: https://zakon.rada.gov.ua/laws/show/640-96- \%D0 \%BF （zvernennya: 07.10.2019)

10. Postanovleniye Pravitel'stva [Government Decree $\mathrm{PM}$ ] "Ob utverzhdenii Kontseptsii razvitiya vodnogo transporta v Respublike Moldova" ["On approval of the Concept of water transport development in the Republic of Moldova"] Nr. 453 ot 24.03.2008. Monitorul Oficial Nr. 66-68 stat'ya № : 433

11. Stattya 2 Zakona RM [Article 2 oftheLawofRM]"On the Inland Water Transport of the Republic of Moldova. URL: http://lex.justice.md/ viewdoc.php?action=view\&view=doc\&id=349950\&lang=2 (zvernennya: $07.10 .2019)$

\section{Bibliography}

\section{Authored books}

12. Binnenschiffahrts - und Flößereirecht : Erläuterungswerk / Otto Vortisch ; Otto Zschucke. Verlag Berlin : de Gruyter, Erscheinungsdatum: 1938, Umfang/Format XIX, 922 s. URL: https://portal.dnb.de/opac.htm? method=showFullRecord \& currentResultId $=\% 22$ Binnenschiffahrts $\% 22+$ and + $\% 22$ und $\% 22+$ and $+\% 22 \mathrm{Fl} \% \mathrm{C} 3 \% \mathrm{~B} 6 \% \mathrm{C} 3 \% 9 \mathrm{Fereirecht} \% 3 \mathrm{~A} \% 22+\mathrm{and}+\% 22 \mathrm{Erl}$ $\%$ C3\%A4uterungswerk\%22\%26any\&currentPosition=1 07.10.2019).

13. Binnenschiffahrtsrecht: Kommentar / Vortisch, Otto, Bemm, Wilfrid. Ausgabe 4., völlig neu bearb. Aufl. / Verlag Berlin; New York: de Gruyter, Erscheinungsdatum: 1991. 819 s. URL: https://portal.dnb.de/opac.htm?query= Otto+Vortisch \%2C+Wilfrid+Bemm\&method=simpleSearch (zvernennya:07.10.2019).

14. Binnenschiffahrtsrecht: Kommentar / von Thor v. Waldstein; Hubert Holland. Ausgabe 5., völlig neu bearb. Aufl. ,VerlagBerlin: de Gruyter Recht, Erscheinungsdatum: 2007. 1104 s. URL: https://portal.dnb.de/opac.htm? method=showFullRecord\&currentResultId=Thor+and+v.+and+Waldstein \%26 any\&currentPosition $=7$ (zvernennya:07.10.2019)

15. Canals and inland waterways.- Encyclopaedia Britannica. URL: https://www.britannica.com/technology/canal-waterway (zvernennya:18.06.2019 p).

16. Ein Service des Bundesministeriums der Justiz und für Verbraucherschutz sowie des Bundesamts für Justiz. URL: (zvernennya:07.10.2019) 
17. Htuicnhjdf rybuf celty / Rbïd? 2018. Register of ships? Kyiv., 2019. URL: http://shipregister/ua|pdf|reg-ships/pdf/ (zvernennya:01/10/2019)

18. Inland waterways $\&$ ports in action. - efip - european federation of inland ports (efip -yevropeys'ka federatsiya vnutrishnikh portiv) URL: https://www.inlandports.eu/views/declaration-inland-waterways-ports-inaction (zvernennya 05.11.2019)

19. Jahresbericht 2018 Europäische Binnenschifffahrt marktbeobachtung. URL: https://www.ccr-zkr.org/files/documents/om/om18_II_de.pdf (zvernennya: $18.06 .2019 \mathrm{p}$ ).

20. Ministerul Transporturilor. RAPORT DE ACTIVITATE pentru anul 2018. IUNIE 2019. Cai fluviale navigabile de folosinta generala. Lungimea cailor de comunicatie, la sfirsitul anului, 2000-2018 pe Indicatori si Ani 2018. URL: $\quad$ http://www.mt.gov.ro/web14/documente/interes-public/rapoarte/ Raport\%20activitate\%20MT\%202018.pdf(zvernennya: 30.09.2019)

21. Paradoxul cu care se confruntă România. Investitorii preferă să importe prin portul olandez Rotterdam. URL: https://www.digi24.ro/stiri/ economie/transporturi/de-ce-investitorii-din-vestul-tarii-prefera-sa-importeprin-portul-olandez-rotterdam-875078 (zvernennya:18.06.2019 p).

22. Thor v. Waldstein, Hubert Holland. - Binnenschiffahrtsrecht: Kommentar. Berlin: de Gruyter Recht, 2007. S. 9-10. URL: https://books.google.com.ua/books?id=i7ViXwMMwokC\&printsec=frontcove $\mathrm{r} \& \mathrm{hl}=\mathrm{ru} \&$ source $=\mathrm{gbs} \_\mathrm{ge} \_$summary_r$\& \mathrm{cad}=0 \# \mathrm{v}=$ onepage $\& \mathrm{q} \& \mathrm{f}=$ false (zvernennya:18.06.2019 p).

23. Shche odyn moldavs'kyy korabel' potrapyv pid zaborony: stala vidoma prychyna. URL: http://bloknot-moldova.md/news/eshche-odin-moldavskiykorabl-popal-pod-zaprety-st-1092650?sphrase_id=955777. 30.09.2019).

24. Yefymenko A. P. "Mizhnarodno-pravovyy rezhym Dunayu: aspekty sudnoplavstva ta okhorony navkolyshn'oho seredovyshcha". ["International legal regime of the Danube: aspects of navigation and environmental protection"] Spetsial'nist' 12.00.11 - mizhnarodne pravo. Avtoreferat. dysertatsiyi na zdobuttya naukovoho stupenya kandydata yurydychnykh nauk. Kyyiv, 1998. $20 \mathrm{~s}$.

25. Informatsiya pro vodnyy transport Ukrayiny. Ukrayina maye 3 sudnoplavni richky, dvi z yakykh vkhodyat' do TOP-5 naybil'shykh richok Yevropy, 16 richkovykh portiv ta terminaliv; $60 \mathrm{mln}$. tonn propusknoyi zdatnosti na rik.[Information about water transport of Ukraine. Ukraine has 3 navigable rivers, two of which are among the top 5 largest rivers in Europe, 16 river ports and terminals; 60 million tonnes of throughput per year.] URL: https://mtu.gov.ua/content/informaciya-pro-vodniy-transport-ukraini.html (zvernennya:04.10.2019) 
26. "Informatsiya pro vodnyy transport Ukrayiny" ["Information about water transport of Ukraine"]. URL: https://mtu.gov.ua/content/informaciyapro-vodniy-transport-ukraini.html (zvernennya:18.06.2019 r).

27. Kazanskiy P. "Dohovirnirichky: Narysy istoriyi ta teoriyi mizhnarodnoho richkovoho prava" ["Contractual Rivers: Essays on the History and Theory of International River La "] T. 1-2 / Kazans'kyy P., priv.-dots. Imp. Kazan. un-tu. Kazan’: Typo-lyt. Imp. un-tu: Typ. Hub. pravl., 1895. 872 s. repryntne kopiya.

28. "Karta yevropeys'kykh vnutrishnikh vodnykh shlyakhiv". ["Map of European Inland Waterways"]. URL: http://mapinmap.ru/archives/9552. (zvernennya: 07.10.2019)

29. Kul'ko A. V. "Instytutsiyni ta dohovirni mekhanizmy rehlamentatsiyi mizhnarodnoho spivrobitnytstva $\mathrm{z}$ vykorystannya resursiv riky Dunay" ["Institutional and contractual mechanisms for regulating international cooperation on the use of Danube river resources"]: avtoref. dys... kand. yuryd. nauk: 12.00.11 / A. V. Kul'ko; Kyiv. nats. un-t im. T. Shevchenka. K., 2009. 19 s. ukp. Kul'ko A. V. Mizhnarodno-pravove rehulyuvannya vykorystannya ta okhorony transkordonnykh prisnykh vod 12.00.11 - mizhnarodne pravo avtoreferat dysertatsiyi na zdobuttya naukovoho stupenya doktora yurydychnykh nauk Kyiv - 2018 avtoreferat dysertatsiyi na zdobuttya naukovoho stupenya doktora yurydychnykh nauk Kyiv, 2018. URL: http://idpnan.org.ua/files/kulko-a.v.-mijnarodno-pravove-regulyuvannyavikoristannya-ta-ohoroni-transkordonnih-prisnih-vod-_a_.pdf （zvernennya: 18.06.2019 r).

30. Labunets A. V. "Ekonomika Moldovy: problemy vodnoho transportu". URL: https://ava.md/2010/07/15/ekonomika-moldovy-problemy-vodnogo transporta ["Moldova's economy: problems of water transport"] (zvernennya: 30.09.2019)

31. Transportni protsesy ta mors'ki mahistrali. [Logistic processes and shipping lanes] II. Proekt mayster-planu "LOGMOS" Dodatok 9.1. Ohlyad krayiny. Moldova. Zhovten' 2013 r URL: http://www.tracecaorg.org/fileadmin/fmdam/TAREP/65ta/Master_Plan/MPA9.1MDRU.pdf.(Zvernennya 07.10.2019).

32. Moshak H. H. "Pravovyy kontrol" vykorystannya richky Dunay". ["Legal control of the use of the Danube River"]. Odesa, "Yurydychna literatura", 2005. $48 \mathrm{~s}$.

33. Pravyla reyestratsiyi suden $\mathrm{v}$ Moldovi zminyuyut'sya.[Rules for registering ships in Moldova are changing]. PortN'yus. URL: http://portnews.ru/digest/20781/. (zvernennya: 30.09.2019).

34. Samoylenko H. V. "Dohovir vantazhiv u vnutrishn'omu vodnomu spoluchenni". ["Cargo contract in inland waterway connection".] Spetsial'nist': 12.00 .03 - tsyvil'ne pravo ta tsyvil'nyy protses; simeyne pravo; 
mizhnarodne pryvatne pravo. - avtoreferat dysertatsiyi na zdobuttya naukovoho stupenya kandydata yurydychnykh nauk. Kharkiv, 2003.

35. Samoylenko Ye. A. mizhnarodno-pravove rehulyuvannya navihatsiynoho vykorystannya mizhnarodnykh rik.-avtoreferat dysertatsiyi na zdobuttya naukovoho stupenya kandydata yurydychnykh nauk. Kyiv, 2016. 46 s. Samoylenko Ye. A. Mizhnarodno-pravove rehulyuvannya sudnoplavnoho vykorystannya mizhnarodnykh rik. Monohrafiya. Kyyiv Vydavnytstvo Lira-K, 2017 [International legal regulation of navigational use of the international year.]

36. Stratehiyeyu peredbacheno v t.ch. rozvytok vnutrishn'oho sudnoplavstva (koordinatory - Avstriya i Rumyniya. Stratehiya Yevropeys'koho Soyuzu dlya Dunays'kyy rehionu [The strategy provides, incl. development of inland navigation (coordinators - Austria and Romania. Strategy of the European Union for the Danube Region] (The EU Strategy for the Danube Region (EUSDR). URL: http://www.me.gov.ua/Documents/Print? lang=uk-UA\&id=529fde16-08e8-45f8-ba31-6c9d36c01254. 07.10.2019).

\section{Information about the author:} Moshak G. G.,

Professor, Doctor of Law, Head of the Department of Civil and Labour Law, Odessa National Maritime University 34, Mechnikov str., Odessa, 65029, Ukraine ORCID ID: orcid.org/0000-0002-4234-9943 